\title{
Manufacture of Labneh from Cow's MilkUsing Ultrafiltration Retentate with or WithoutAddition of Permeate Concentrate
}

\author{
Shamsia S. M., ${ }^{1}$ and El-Ghannam M. S. ${ }^{2}$
}

\begin{abstract}
Chemical composition, rheological properties and sensory evaluation of fresh labneh made from cow's milk, using ultrafiltration (UF) retentate and traditional process were investigated.

Coagulation time showed a synergetic effect of addition of both glucono delta lactone (GDL1\%) and permeate concentrate $(1 \%)$ on coagulation time of labneh where the two components have been accelerated the acidity development. Consequently, the coagulation time becomes shorter.
\end{abstract}

Addition of $1 \%$ permeate concentrate, $1 \%$ or $2 \%$ GDL already increased total solids significantly.

Chemical composition of labneh showed that total solids, total protein, soluble protein, fat, ash, acidity and pH were increased in labneh made from UF retentate comparing with that traditionally prepared. pH was higher in UF labneh although acidity content was markedly higher than that of traditionally prepared one. Soluble protein content was trebled in UF retentate labneh. Lactose content was lower in UF labneh than control except those treatments where permeate concentrate was added.

Texture profile test showed that a correlation between acidity, coagulation time and hardness may be exist. Results also showed that there is no definite correlations between the additions of permeate concentrate or GDL and springiness or adhesiveness of labneh. Addition of $1 \%$ permeate concentrate has lowered the cohesiveness values, while addition of $1 \%$ GDL had no effect. Values of resilience are consistent with those of cohesiveness. Wide variations were observed among treatments.

Addition of $1 \%$ permeate concentrate to the UF labneh improved the appearance, consistency and flavor of produced labneh.

Key words: Labneh, rheology, retentate, cow's milk.

\section{INTRODUCTION}

Labneh or strained/concentrated yogurt is a traditional fermented milk product. It is a popular food in various parts of the world especially in the Middle East chiefly Turkey and Balkan regions where it plays a significant role in the family diet (Tamime \& Robinson, 1978). Labneh has increased in popularity during the last years. Its perceived nutritional benefits and storage characteristics have led to its increasing economic importance (Benezech \& Maingonnat, 1994 and Nsabimana, et al. 2005).

Labneh has been manufactured and studied from cow's milk by several researchers (Tamime and Robinson, 1978, 1988; Abou-Donia et al., 1992a\&b and AlKadamany et al., 2003) and produced, in commercial scale by large dairy plants, in the Mediterranean and the Middle East countries.

Usually, labneh is prepared with two solids concentration ranges either around 22 weight $\%$ or around 40 weight \% (labneh anbaris). The former is prepared to be consumed within two weeks and usually stored in refrigerators; the other one is stored in vegetable oil at room temperature and can be consumed within two years (Keceli, et al. 1999).

The traditional method for producing labneh consists of straining whole-milk yogurt in cheese cloth bags to the desired total solids level (22-26\%). Texture of labneh determines the identity and acceptability of the product. It is characterized by a smooth and pasty texture with a semisolid mass (Mustafa, 1978; Rosenthal et al.980 and Tamime \& Crawford, 1984). However, much of its consumer acceptability is dependent on its sensory properties, which in turn, seem to be heavily dependent on the method of processing of the material. Modern techniques are now increasingly used to make labneh. However, ultrfiltration (UF) process was proposed as a better alternative to the traditional labneh-making process, which is uneconomical and unhygienic (Ozer et al., 1999a \& b; EI-Samragy et al., 1997; EI-Samragy and Zall, 1988; Tamine et al., 1989a\&b and $1991 \mathrm{a \& b}$ ).

Although labneh has been manufactured from cow's milk using UF-process in the last two decade, published reports on composition and quality characteristics are relatively limited (Tamine et al., 1991 b).

Therefore, the objectives of this work were to:

1-Characterize the compositional properties of labneh made from cow's milk (UF) retentate in comparison with the traditionally prepared labneh from normal cow's milk.

\footnotetext{
${ }^{1}$ Department of Food and Dairy Science \& Technology,

Faculty of Agriculture ,Damanhour University, Egypt.

${ }^{2}$ Department of Dairy Science \& Technology,

Faculty of Agriculture (El-Shatby), Alexandria University, Egypt.

Received February 26, 2012, Accepted March28, 2012
} 
2- Evaluate the rheological and sensorial properties of labneh manufactured by traditional and UF retentate with or without addition of permeate concentrate.

\section{MATERIALS AND METHODS}

\section{Materials:}

Milk

Cow's milk $(3.3 \%$ fat $-12 \%$ total solids $)$ was obtained from the herds of Nasser Secondary School of Agriculture, Damanhour, Beheira, Governorate, Egypt.

\section{Permeate concentrate}

Permeate concentrate powder $(84 \%$ lactose $-11 \%$ ash $-4 \% \mathrm{H}_{2} \mathrm{O}$ ) was imported from BMI Co. Germany.

\section{Glucono delta lactone (GDL)}

Glucono delta lactone (GDL) was imported from Shandong Kaison Biochemical Co., LTD, Wulian Country, Shandong China.

\section{Lactic acid bacteria starter}

Lactic acid culture (MAO 16, 20u. Texel, France) containing Streptococcus salivarius ssp. thermophilus and Lactobacillus delbruckii ssp. bulgaricus was supplied from Dairy Pilot Plant, Faculty of Agriculture, Alexandria University, Egypt.

\section{Methods \\ Ultrafiltration}

Ultrafiltration equipment was installed in the pilot plant of Nasser Secondary School of Agriculture, Damanhour, Beheira . Cows' milk (3.3\% fat $-12 \%$ total solids) was concentrated to two times $(22.97 \%$ total solids) using a module type of Tubular UF unit "Carbosep Company ", Model 2S 37 (with surface area $2 \times 0.48 \mathrm{~m}^{2}$ ). Patent design consists of a layer of zirconium oxide on a carbon support. The unit was operated with inlet pressure of 5-6 bar and outlet pressure of 2-3 bar at $50 \pm 2{ }^{\circ} \mathrm{C}$. The fresh raw cow's milk and retentate were immediately pasteurized at 63 ${ }^{\circ} \mathrm{C}$ for $30 \mathrm{~min}$ and cooled to $4{ }^{\circ} \mathrm{C}$ and labneh treatments were immediately prepared.

The following six labneh preparations were made as follows:

\section{Labneh made using traditional method (control)}

Pasteurized cow's milk was warmed to $40^{\circ} \mathrm{C}$, inoculated with $2 \%(\mathrm{wt} / \mathrm{wt})$ commercial lactic culture (DVS YY47) and incubated until coagulation. The resultant yoghurt was overnight refrigeration drained in double layer cheese cloth bags until the desired total solids concentration was reached, which is typical of traditional labneh from the Middle East Tamime and Robinson (1985). The resultant labneh were packaged in PVC containers $(250 \mathrm{~g})$ and used as control.

\section{Treatments of Labneh made from UF retentate}

Treatment1: Pasteurized retentate was warmed to $40^{\circ} \mathrm{C}$, inoculated with $2 \%(\mathrm{wt} / \mathrm{wt})$ commercial lactic culture (DVS YY47). Sample were packaged in PVC containers $(250 \mathrm{~g})$ and incubated at $40^{\circ} \mathrm{C}$, until coagulation.

Treatment 2: pasteurized retentate was warmed to $40^{\circ} \mathrm{C}$, inoculated with $4 \%$ (wt/wt) Commercial lactic culture (DVS YY47). Sample were packaged in PVC containers $(250 \mathrm{~g})$ and incubated at $40^{\circ} \mathrm{C}$, until coagulation.

Treatment 3: Pasteurized retentate was warmed to $40^{\circ} \mathrm{C}$ and mixed with $1 \%$ (wt/wt) permeate concentrate powder, and then inoculated with $2 \%$ (wt/wt) commercial lactic culture (DVS YY47). Sample were packaged in PVC containers $(250 \mathrm{~g}$ ) and incubated at $40^{\circ} \mathrm{C}$, until coagulation.

Treatment 4: Pasteurized retentate was warmed to $40^{\circ} \mathrm{C}$ and mixed with $2 \%$ (wt/wt) GDL then, inoculated with 2\% (wt/wt) commercial lactic culture (DVS YY47). Sample were packaged in PVC containers $(250 \mathrm{~g})$ and incubated at $40^{\circ} \mathrm{C}$, until coagulation.

Treatment 5: Pasteurized retentate was warmed to $40^{\circ} \mathrm{C}$ and mixed with $1 \%$ (wt/wt) permeate concentrate powder $+1 \%(\mathrm{wt} / \mathrm{wt})$ GDL then, inoculated with $2 \%$ (wt/wt) commercial lactic culture (DVS YY47). Sample were packaged in PVC containers $(250 \mathrm{~g})$ and incubated at $40^{\circ} \mathrm{C}$, until coagulation.

\section{Methods of analysis \\ Samples}

Fresh representative samples were taken from each treatment for chemical analysis, rheological measurements and sensory evaluation.

\section{Chemical analysis}

Total solids content were determined according to the British Standard Institution Bulletin (1952).

$\mathrm{pH}$ values were measured using a $\mathrm{pH}$-meter model HANNA HI9321 microprocessor with a standard, combination glass electrode British Standard Institution Bulletin (1952).

Titratable acidity was estimated as percentage of lactic acid according to Ling (1963).

Lactose content was determined according to the Lawrence Method (1968).

Fat content was determined according to British Standard Institution Bulletin (1955).

Total and soluble nitrogen and ash content were determined as described in the Association of Official Analytical Chemists (1984). 
Coagulation time was recorded from the time of placing the containers in the incubator until the contents become completely settled.

\section{Textural properties}

The Textural Profile Analysis test (TPA) for some textural properties (hardness, springiness, adhesiveness, cohesiveness and resilience) were measured by LFRATexture analyzer (1000) using computer interface software (CNS Farnell, Bore Harwood, Hertfordshire, England WD6 1WG) according to Breene (1975) and Bourne (1978).

\section{Sensory evaluation}

Sensorial properties were evaluated by ten panelists familiar with the product after overnight storage of the samples at $5^{\circ} \mathrm{C}$. Sensory characteristics were appearance (5 points), texture (5 points), flavor (10 points) with total score of 20 points Pearce and Heap (1974).

\section{Statistical analysis}

All obtained data were statistically analyzed using SAS software program (2000).

\section{RESULTS AND DISCUSSIONS}

\section{Coagulation time}

Coagulation time of prepared labneh (Table1) was varied among treatments and between treatments and control. Beside the control sample, Tr.1 represents the basic formula of treatments. The longest coagulation time was recorded for Tr.1 and Tr.2 those made only from retentate and starter culture. The prolonged coagulation time is due to the higher buffering capacity of high protein content of retentate. Despite Tr.2 contained the double amount of starter culture added to Tr.1, the coagulation time was the same $(4: 45 \mathrm{hr})$ that means that the smaller amount $(2 \%)$ of starter culture added to Tr.1 was sufficient to produce enough acidity to induce coagulation.

Table 1. Coagulation time of labneh produced by using pasteurized cow's milk for traditional method and pasteurized cow's milk retentate for treatments

\begin{tabular}{lc} 
Treatments & $\begin{array}{c}\text { Coagulation time } \\
\text { hr.:min. }\end{array}$ \\
\hline Traditional (control) & $3: 00$ \\
\hline Tr.1 & $4: 45$ \\
\hline Tr.2 & $4: 45$ \\
\hline Tr.3 & $4: 00$ \\
\hline Tr.4 & $2: 45$ \\
\hline Tr.5 & $3: 00$ \\
\hline
\end{tabular}

Traditional (control) $=$ Pasteurized cow's milk $+2 \%$ lactic culture.

Tr. $1=$ Pasteurized retentate $+2 \%$ lactic culture .

$\operatorname{Tr} .2=$ Pasteurized retentate $+4 \%$ lactic culture .

$\operatorname{Tr} .3=$ Pasteurized retentate $+1 \%(\mathrm{wt} / \mathrm{wt})$ permeate concentrate $+2 \%$ lactic culture.

Tr. $4=$ Pasteurized retentate $+2 \%(\mathrm{wt} / \mathrm{wt}) \mathrm{GDL}+2 \%$ lactic culture .

Tr. $5=$ Pasteurized retentate $+1 \%(\mathrm{wt} / \mathrm{wt})$ permeate concentrate $+1 \%(\mathrm{wt} / \mathrm{wt}) \mathrm{GDL}+2 \%$ lactic culture.
On the other hand, Tr.4 which has similar constituents to Tr.1 plus 2\% GDL had the shortest coagulation time $(2: 45 \mathrm{hr})$. It can be attributed this result to the acidity produced from GDL which shortly developed faster than the developing acidity produced by the starter causing coagulation in a short time.

Addition of $1 \%$ permeate concentrate that contains $84 \%$ lactose (Tr.3) enhanced the coagulation process and led to moderate coagulation time (4:0hr). Coagulation time of Tr.5 was similar to that of control (3:0hr) showing the synergetic effect of addition of both GDL $(1 \%)$ and permeate concentrate $(1 \%)$ on coagulation time where the two components have been accelerated the acidity development consequently, the coagulation time become shorter.

From the above results, it can be concluded that the addition of GDL is important to develop sufficient acidity for coagulation in a reasonable time and addition of permeate concentrate enhanced the development of acidity induces coagulation. On the other hand, addition excess of starter culture more than $2 \%$ did not shorten the coagulation time.

\section{Chemical composition}

Table 2 showed the chemical composition of prepared labneh. Total solids were significantly higher in all treatments comparing with the control. Among treatments where Tr. 1 represents the basic formula, total solids of Tr.1 and Tr.2 were nearly similar and significantly lower than the other three treatments. Differences between Tr.3, tr.4 and Tr.5 are significant where Tr.3 had the highest total solids followed by tr.5 then Tr.4. Addition of $1 \%$ permeate concentrate already increased total solids of Tr.3 and Tr.5. Also addition of $2 \%$ GDL to Tr.4 significantly increased total solids comparing with Tr.1. 
Table 2. Chemical composition of labneh produced by using pasteurized cow's milk for traditional method and pasteurized cow's milk retentate for treatments

\begin{tabular}{lcccccccc}
\hline \multirow{2}{*}{ Treatments } & \multicolumn{9}{c}{ Composition \% } & A & Ash & Acidity & pH \\
\cline { 2 - 9 } $\begin{array}{l}\text { Traditional } \\
\text { (control) }\end{array}$ & $22.31^{\mathrm{d}}$ & $7.85^{\mathrm{d}}$ & $0.65^{\mathrm{b}}$ & $8.6^{\mathrm{a}}$ & $4.11^{\mathrm{b}}$ & $1.03^{\mathrm{d}}$ & $1.54^{\mathrm{d}}$ & $4.96^{\mathrm{e}}$ \\
\hline $\operatorname{Tr} .1$ & & & & & & & & \\
\hline $\operatorname{Tr} .2$ & $22.93^{\mathrm{c}}$ & $8.93^{\mathrm{ab}}$ & $1.73^{\mathrm{a}}$ & $8.7^{\mathrm{a}}$ & $3.53^{\mathrm{d}}$ & $1.16^{\mathrm{bc}}$ & $2.18^{\mathrm{c}}$ & $5.19^{\mathrm{a}}$ \\
\hline $\operatorname{Tr} .3$ & $22.84^{\mathrm{c}}$ & $8.99^{\mathrm{a}}$ & $1.70^{\mathrm{a}}$ & $8.6^{\mathrm{a}}$ & $3.50^{\mathrm{d}}$ & $1.12^{\mathrm{c}}$ & $2.41^{\mathrm{ab}}$ & $5.12^{\mathrm{bc}}$ \\
\hline $\operatorname{Tr} .4$ & $23.36^{\mathrm{a}}$ & $8.82^{\mathrm{c}}$ & $1.77^{\mathrm{a}}$ & $8.6^{\mathrm{a}}$ & $4.24^{\mathrm{a}}$ & $1.28^{\mathrm{a}}$ & $2.38^{\mathrm{b}}$ & $5.14^{\mathrm{b}}$ \\
\hline $\operatorname{Tr} .5$ & $23.19^{\mathrm{b}}$ & $8.81^{\mathrm{c}}$ & $1.74^{\mathrm{a}}$ & $8.7^{\mathrm{a}}$ & $3.48^{\mathrm{c}}$ & $1.14^{\mathrm{c}}$ & $2.47^{\mathrm{a}}$ & $5.05^{\mathrm{d}}$ \\
\hline
\end{tabular}

LSD P $\leq 0.05=0.109,0.837,0.169,0.308,0.116,0.0889,0.059$ and 0.016 for T.S., T.P., S.P., F, L, ash, acidity and pH respectively

Total solids of retentate labneh can be precisely adjusted while traditional labneh cannot. Also addition of permeate concentrate and GDL increase total solids content which may improve the texture and consistency and may be sensory characteristics of labneh.

Tamime et al. (1989a) stated that total solids and fat contents were 24.2 and $8.2 \%$ respectively for cow's milk labneh made by the traditional method, while ElSmaragy and Zall (1988) found that the total solids was $23.18 \%$ of labneh made from ultrafiltrated cow's milk. Hefnawy et al. (1992) indicated that the total solids were 22.42 and $23.24 \%$ for cow's and buffalo's milk labneh respectively. Ozer et al. (1999a\&b) reported that the traditional (control) labneh had higher total solids, fat and protein contents than did labnehs produced by UF process. These differences may be attributed to the extent of draining and resulting increased concentration of the solids contents.

Ozer et al. (1999a\&b) found that the chemical composition of traditional labneh is different from ultrafiltration and reverse osmosis membrane processing.

Protein content was significantly higher in all treatments comparing with the control. Tr.1 and Tr.2 had the highest protein content followed by Tr.5 and then Tr.3 and Tr.4. Although differences among treatments are mostly significant, the actual differences showed in table 2 are $0.01 \%$ as minimum and $0.18 \%$ as maximum between the highest and the lowest percentage of protein content of retentate labneh. It is fact that milk retentate retains the soluble protein which is releasing with whey when the traditional method of labneh manufacturing is applied. Therefore, the elevated protein content of retentate labneh comparing with the control is expected. Differences among treatments may due to addition of GDL and or permeate concentrate that lowering the final protein content of retentate labneh. Moreover, differences in protein content among treatments are not too much to be effective on the nutritional value of different retentate labneh.

Aumara and Farahat (2007) reported that the traditional labneh had lower fat and total protein contents than UF-labneh, which was expected as double layer cloth bags allowed the separation of some fats and proteins especially whey proteins and some protein derivatives. Conversely, with UF, some constituents were concentrated in proportion of concentration factor.

Soluble protein (SP) content of produced labneh followed similar trend as protein content. It was raised nearly three times in retentate labneh comparing with its ratio in traditionally prepared labneh. Consequently it was significantly higher in all treatments than the control, but among treatments there were no significant differences.

Fat content of traditionally prepared labneh as well as retentate one was nearly constant, therefore no significant differences were observed.

Lactose content showed wide variations among treatments and between control and treatments. The idea behind the addition of permeate concentrate $(84 \%$ lactose) was firstly to bring back the reduced ratio of lactose in retentate (as a result of ultrafiltration) to the original ratio of lactose in normal milk as it is the substrate of the starter bacteria to produce acidity enough to coagulation and secondly to raise the total solids of the produced labneh. Lactose content of control and Tr.3 and Tr.5 was round $4.1 \%$ while it was significantly lower in Tr.1, Tr.2 and Tr.4 where it was round $3.5 \%$. Addition of permeate concentrate to Tr.3 and Tr.5 increased their content of lactose to be close to the ratio of lactose in traditionally produced labneh.

Ash content was significantly increased in all treatments comparing with the control. Differences among treatments were significant between Tr.1, Tr.2, Tr.3 and Tr.5, while it was not significant between Tr.2 
and Tr.4. The increased ash content of Tr.3 and Tr.5 is due to addition of permeate concentrate.

Acidity was significantly higher in all treatments comparing with the control. Significant differences were observed among the following treatments: Tr.1, Tr.2, Tr.3 and Tr.4 while acidity of Tr.2 and Tr.5 was the same. Tr. 4 had the highest acidity. It can be noticed that the acidity development was not correlated with the addition of permeate concentrate but with the addition of GDL. This result is consistent with the result of coagulation time (table1) where Tr.4 had the shortest coagulation time.El-Smaragy and Zall (1988) found that the acidity of labneh was $1.63 \%$.

$\mathrm{pH}$ values were significantly higher in all treatments comparing with the control. Differences among treatments were also significant. $\mathrm{pH}$ of traditionally produced labneh was nearly 5.0 while $\mathrm{pH}$ of retentate labneh was round 5.1. This difference is not consistent with the determined acidity values. It reflects the great buffering capacity of retentate which hide the higher acidity developed in retentate labneh in comparison with the traditionally produced one. Results obtained for coagulation time are consistent with the measured $\mathrm{pH}$ values.

The $\mathrm{pH}$ (4.0-5.0), titratable acidity(2.7\%), chemical composition $(74.57 \%$ moisture, $8.3 \%$ protein, $9.8 \%$ fat, $6.37 \%$ lactose and $1.17 \%$ ash) of labneh, produced by blending concentrated skim milk yogurt with cream, (Yamani \& Abu-Jaber, 1994; El-Samragy et al., 1988; Tamime \& Robinson, 1988).

\section{Textural properties}

Hardness, springiness, adhesiveness, cohesiveness and resilience as textural properties of labneh have been shown in table 3 . Hardness is the force required to compress a sample between the molars (Szczesniak et al., 1963; Bourne, 1978).

Hardness was widely varied among treatments while traditionally made labneh had intermediate value. Tr.2 had the highest hardness value, the high level of hardness comparing to control is due to high level of milk protein in these sample, While Tr.4 which had GDL $2 \%$, the highest acidity and the shortest coagulation time had the lowest hardness value, these may be due to the effect of reduction $\mathrm{pH}$ value in dissociation of colloidal calcium phosphate (CCP) from the casein micelle. Tr.5 that contained $1 \%$ permeate concentrate and had relatively high acidity and short coagulation time had relatively low hardness value. A correlation between acidity, coagulation time and hardness may be exist.

Springiness is the rate at which a deformed material returns to its original shape on removal of the deforming force (Szczesniak et al., 1963; Bourne, 1978).

Springiness reflects the rubbery property of the produced labneh. It is unfavorable to be found as distinctive property in labneh. It was slightly varied among treatments and control and there is no definite effects of addition of permeate concentrate or GDL on the springiness of labneh.

Adhesiveness is the tendency of labneh material to adhere with other material or surface. Tr.5 had the highest adhesiveness value, Tr.4 and control as well as Tr. 1 and Tr.3 had nearly similar adhesiveness values. Tr.2 had relatively low adhesiveness value. These results showed that there is no definite correlations between the additions of permeate concentrate or GDL adhesiveness of produced labneh. Cohesiveness is the strength of internal bonds making up the body of the product (Szczesniak et al., 1963; Bourne, 1978). It is a parameter for measuring the ability of labneh particles to adhere with each other. It can be noticed that Tr.3 and Tr.5 had the lowest cohesiveness values where permeate concentrate was added. Traditionally made labneh and Tr.4 (which had the highest acidity and the shortest coagulation time) had intermediate cohesiveness values that mean that addition of GDL had no effect on cohesiveness.

Resilience is the ability of labneh to recover its original shape. Values of resilience are consistent with those of cohesiveness. Wide variations were observed among treatments with minimum values for Tr.3 and Tr.4.

\section{Sensory evaluation}

Sensory evaluation of labneh has been shown in table 4. Labneh made by the traditional method gained high score for appearance, texture and flavor with total score of 16 points out of 20 points. On the other hand, Tr.4 which had the shortest coagulation time and contained 2\% GDL gained the lowest score of appearance, texture and flavor with total score of 13.5 points. Tr. 1 had the highest texture and flavor, Tr. 2 had the lowest appearance, Tr. 3 and Tr. 5 had high score for appearance, texture and flavor for Tr.3 and slightly lower flavor score for Tr.5. Therefore the best sensory properties among treatments and control are of Tr.3 where $1 \%$ permeate concentrate was added to the basic formula followed by Tr.1 (basic formula), control and finally Tr.5.

It can be concluded that the addition of $1 \%$ permeate concentrate to the basic formula of retentate labneh (retentate $+2 \%$ lactic culture) improved the appearance, consistency and flavor of produced labneh. 
Table 3. Textural properties of labneh produced by using pasteurized cow's milk for traditional method and pasteurized cow's milk retentate for treatments

\begin{tabular}{|c|c|c|c|c|c|}
\hline \multirow[b]{2}{*}{ Treatments } & \multicolumn{5}{|c|}{ Textural properties } \\
\hline & $\begin{array}{c}\text { Hardness } \\
\text { (g) }\end{array}$ & $\begin{array}{c}\text { Springiness } \\
(\mathrm{mm})\end{array}$ & Adhesivenessg.sec & $\begin{array}{c}\text { Cohesiveness }(\mathrm{g} / \mathrm{cm} \\
)\end{array}$ & Resilience \\
\hline $\begin{array}{l}\text { Traditional } \\
\text { (control) }\end{array}$ & 2586 & 0.973 & -560 & 0.427 & 0.151 \\
\hline Tr.1 & 2875 & 0.975 & -682 & 0.445 & 0.174 \\
\hline Tr.2 & 3171 & 0.963 & -668 & 0.459 & 0.179 \\
\hline Tr.3 & 2313 & 0.975 & -695 & 0.391 & 0.107 \\
\hline Tr.4 & 1945 & 0.995 & -553 & 0.427 & 0.111 \\
\hline Tr.5 & 2014 & 0.938 & -723 & 0.414 & 0.130 \\
\hline
\end{tabular}

Table 4.Sensory evaluation of labneh produced by using pasteurized cow's milk for traditional method and pasteurized cow's milk retentate for treatments

\begin{tabular}{lcccc}
\hline \multirow{2}{*}{ Sample } & \multicolumn{2}{c}{ Sensory properties } \\
\cline { 2 - 5 } & Appearance & Texture & Flavor & Total \\
\hline Traditional (control) & $4^{\mathrm{a}}$ & $4^{\mathrm{a}}$ & $8^{\mathrm{ab}}$ & $16^{\mathrm{ab}}$ \\
\hline $\operatorname{Tr} .1$ & $3.3^{\mathrm{a}}$ & $4.5^{\mathrm{a}}$ & $9^{\mathrm{a}}$ & $16.8^{\mathrm{a}}$ \\
\hline $\operatorname{Tr} .2$ & $3^{\mathrm{a}}$ & $4^{\mathrm{a}}$ & $8^{\mathrm{ab}}$ & $15^{\mathrm{ab}}$ \\
\hline $\operatorname{Tr} .3$ & $4.3^{\mathrm{a}}$ & $4.5^{\mathrm{a}}$ & $8^{\mathrm{ab}}$ & $16.8^{\mathrm{a}}$ \\
\hline $\operatorname{Tr} .4$ & $3^{\mathrm{a}}$ & $3.5^{\mathrm{a}}$ & $7^{\mathrm{b}}$ & $13.5^{\mathrm{b}}$ \\
\hline $\operatorname{Tr} .5$ & $4.5^{\mathrm{a}}$ & $4^{\mathrm{a}}$ & $7.5^{\mathrm{ab}}$ & $16^{\mathrm{ab}}$ \\
\hline
\end{tabular}

$\mathrm{LSD} \leq \mathrm{P} 0.05=1.437,1.406,1.664$ and 2.684 for appearance, texture, flavor and total score respectively.

Ozer and Robinson (1999). Mahmoud (1980), Omar and Buchheim (1986), Hagrass et al. (1986) and Hydamaka et al. (2000) reported that Labneh produced by UF concentration was the preferred option. They also reported that soft white cheeses made from cow's milk by UF had a uniform and closed texture, good appearance and better organoleptic properties than the cheeses made by traditional process.

\section{REFERENCES}

Abou-Donia, S. A., I. A. Attia, A. A. Khattab, and S. M. ElKhadragy, (1992a). Characteristics of labneh manufactured using different lactic starter cultures. Egyptian J. Food Sci., 20: 1-12.

Abou-Donia, S. A., A. A. Khattab, I. A. Attia and S. M. ElKhadragy, (1992b). Effect of modified manufacturing process of labneh on its chemical composition and microbiological quality. Egyptian J. Food Sci. 20: 13-25.

Al-Kadamanya, E., Khattarb, M., Haddadc, T. and Toufeili, I. (2003). Estimation of shelf-life of concentratedyogurt by monitoring selected microbiological andphysicochemical changes during storage. Lebensm.-Wiss. U.-Technol. 36: 407-414.

Association of Official Analytical Chemists (A.O.A.C.) (1984). Official methods of analysis, $14^{\text {th }}$ ed., Washington, DC.
Aumara I.A. and Farahat Azza M. (2007).properties of symbiotic ultrafiltrated labneh along refrigerated storage. Egyption Journal of Dairy Science, 35:201-218.

Benezech, T., \& Maingonnat, J. F. (1994). Characterisation of the rheological properties of yogurt - a review. Journal of Food Engineering, 21, 447-472.

British Standard Institution (B.S.I.) (1952). Method for the chemical analysis of cheese B.S.I. No 770.

British Standard Institution (B.S.I.) (1955). Geber method for the determination of fat in milk and milk products. B.S.I. part 1 and 2.

Bourne, M. (1978). Texture Profile Analysis. Food Technology, 32 (7): 62-66, 72.

Breene, W. (1975). Application of Texture Profile Analysis to instrumental food texture evaluation. Journal of Texture Studies, 6 (53-82)

EI-Samragy, Y. A., M. M. EI-Sayed and N. S. Abd-Rabou, 1997. Nutritive value of labneh as affected by processing methods. Egyptian J. Dairy Sci., 25: 85-97.

EI-Samragy, Y. A. and R. R. Zall, 1988. Organoleptic properties of the yogurt-cheese labneh manufactured using ultrafiltration. Dairy Industries International. $53: 27-28$.

El-Samragy, Y. A., Fayad, E. O., Aly, A. A., \& Hagrass, A. E. A. (1988). Properties of labneh-like product manufactured using Enterococcus starter cultures as novel dairy fermentation bacteria. Journal of Food Protection, 51, 386-390. 
Hagrass, A. E. A., E. Renner and A. E. Fayed, 1986. Comparison between the ultrafiltration and traditional Kariesh cheeses produced from fresh and dried skimmilk. Proceeding of 3'd Egyptian Conference for Dairy Science and Technology. Cairo, Egypt.

Hefnawey, Sh, Ibrahim, S. A. and Abdel-Kader, Sh (1992). Studies on composition and properties of concentrated yoghurt (labneh) manufactured from recombined milk with different vegetable oils. Egyptian J.

Hydamaka, A. W., R. A. Wilbey and M. J. Lewis, 2000. Manufacture of direct acidified cheese from ultrafiltration and reverse osmosis retentates. International Journal Dairy Technol., 53, 120-124.

Keceli, T., Robinson, R. K., \& Gordon, M. H. (1999). The role of olive oil in the preservation of yogurt cheese (labneh anbaris). International Journal of Dairy Technology, 52, 68-72.

Lawrence, A. J. (1968). The determination of lactose in milk products.Australian Journal of Dairy ${ }^{1}$ echnology, 23, 103.

Ling, E. R., 1963. A Text Book of Dairy Chemistry. Chapman and Hall Ltd., London, England.

Mahmoud, M. M., 1980. Ultrafiltration in the manufacture of soft pickled cheese and production of alcohol and single cell protein from whey. Ph. D. thesis, Cornell University, Ithaca, USA.

Mustafa, S. (1978). Microbiological studies on Labneh, a fermented dairy product in Jordan. M.Sc thesis, The university of Jordan,Amman, Jordan.

Nsabimana, C., Jiang, B., \& Kossah, R. (2005). Manufacturing, properties and shelf life of Labneh: a review. International Journal of DairyTechnology, 58(3), 129-137.

Omar, M. M. and W. Buchheim, 1986. Microstructure and composition of soft Domiati cheese made from ultrafiltered milk. Processing of 3rd Egyptian Conference for Dairy Science and Technology, Cairo, Egypt.

Ozer, A. H., \& Robinson, R. K. (1999). The behaviour of starter cultures in concentrated yogurt (Labneh) produced by different techniques. Lebensmittel-Wissenschaft undTechnologie, 32, 391-395, doi:10.1006/fstl.1999.0566.

Ozer, B. H., R. A. Stenning, A. S. Grandison and R. K. Robinson, (1999a). Rheology and microstructure of labneh (concentrated yoghurt). J. Dairy Sci., 82: 682-689.

Ozer, B. H., R. A. Stenning, A. S. Grandison and R. K. Robinson, 1999b. Effect of protein concentration on the properties and structure of concentrated yogurts. International J. Dairy Technol., 52: 135-138.

Pearce, L. E. and Heap, H. A. (1974). Town milk. Journal of the New Zealand Milk Board, 22, 18.

Rosenthal, I., Juven, B. J., Gordin, S., \& Jubran, N. (1980). Characteristics of concentrated yogurt (labneh) produced in Israel. Journal of Dairy Science, 63, 1826-1828.

Szczesniak, A., M. Brandt, and H. Freidman. 1963. Development of standard rating scales for mechanical parameters and correlation between the objective and sensory texture measurements. Food Technol. 22:50-54.

Statistical analysis, SAS Institute. (2000). SAS User's Guide, Version 4.02 . SAS Inst., CARY, N.C.

Tamime, A. Y., \& Robinson, R. K. (1978). Some aspects of the production of a concentrated yogurt (labneh) popular in the Middle East. Milchwissenschaft, 33, 209-212.

Tamime, A. Y., \& Crawford, R. J. (1984). The microbiological quality of yogurt cheese known in the Lebanon as Labneh anbaris after one year storage at 20 _C. Egyption Journal of Dairy Science, 12, 299-312.

Tamime, A. Y. and R. K. Robinson, 1988. Fermented milks and their future trends. Part II. Technological aspects. Journal of Dairy Res., 55: 281-307.

Tamime, A. Y., M. Kalab and G. Davies, 1989a. Rheology and microstructure of strained yoghurt (labneh) made from cow's milk by three different methods. Food Microstructure 8: 125-135.

Tamime, A. Y., G. Davies, A. S. Chehade and H. A. Mandi, 1989b. The production of "Labneh" by ultrafiltration: a new technol. J. Society of Dairy Technol., 42: 35-39.

Tamime, A. Y., G. Davies, A. S. Chehade and H. A. Mandi, 1991a. The effect of processing temperatures on the quality of labneh made by ultrfiltration. J. Society of Dairy Technol., 44: 99-103.

Tamime, A. Y., M. Kalab, G. Davies and H. A. Mandi, 1991b. Microstructure and firmness of labneh (high solids yoghurt) made from cow's, goat's and sheep's milks by a traditional method or by ultrafiltration. Food Structure, 10: 37-44.

Yamani, M. I., \& Abu-Jaber, M. M. (1994). Yeast flora of labneh produced by in-bag straining of cow milk set yogurt. Journal of Dairy Science, 77, 3558-3564. 


\title{
الملخص العربي
}

\section{تصنيع اللبنة من مركز الترشيح الفائق للبن البقرى بإضافة أو عدم إضافة الراشح المركز}

\author{
شريف شمسية، محمود الغنام
}

تضاعفت نسبة البروتين الذائب إلى ثلاثة أضعاف بينما انخفضت نسبة اللاكتوز في اللبنة المصنعة من مركز الترشيح الفائق مقارنة باللبنه المضره بالطريقة التقليدية وذلك لإحتجاز بروتينات الشرش في المركز وتسرب سكر اللاكتوز مع الراشح إلا في المعاملات التى أضيف لها مسحوق الراشح المحفف فقد ارتفعت فيها نسبة سكر اللاكتوز لتصبح مساوية لتلك التي في اللبنه المصنعة من اللبن بالطريقة التقليدية.

أظهرت اختبارات القوام والتركيب texture profile test أن هناك علاقة محتملة بين كل من الحموضة وزمن التجبن والصلابة hardness، بينما لم تتأكد العلاقة بين إضافة أى من الجلو كونو دلتا لاكتون أومسحوق الراشح البحفف وخاصية استعادة الشكل springiness إضافة 1\% مسحوق الراشح المحفف أدى إلى خفض قيم التماسك cohesiveness، بينما إضافة إ\% جلوكونو دلتا لاكتون لم تحدث تأثير وكانت قيم المرونة resilience متمشية مع قيم التماسك cohesiveness. أظهرت نتائج التحكيم الحسى أن إضافة 1\% مسحوق الراشح البحفف إلى اللبنه المصنعة من مركز الترشيح الفائق أدى إلى تحسن خواص المظهر appearance و التركيب consistency و النكهة flavor
إستهدف البحث دراسة تأثير إضافة مسحوق الراشح المحفــف

dry permeate اللبنه لتعويض النقص في نسبة سكر اللاكتوز في المركز وتأثير ذلك

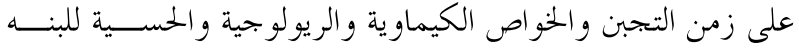
النابتحة.

تم تحضير اللبنه من اللبن البقرى بالطريقة التقليدية ومن مركــــ

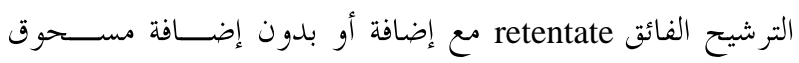

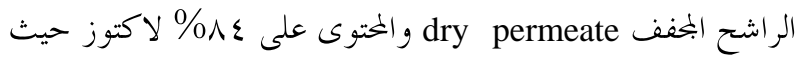
تمت دراسة التركيب الكيماوى والخواص الريولوجية والحسية. أظهرت النتائج تأثيراً تو افقياً synergetic لكل من الجلو كونـــو دلتا لاكتون ومسحوق الراشح المجفف على وقت الــتجبن عنــــــا أضيف كل منهما بنسبة ا\% مركز الترشيح الفائق حيث أدى ذلك إلى سرعة تكون الحموضوضة وبالتالى قصر الوقــت الــلازم للـــتجبن بالمقارنة للعينة المخرة من اللبن بالطريقة التقليدية.

أظهر التحليل الكيماوى زيادة في نسبة كل من المادة الصلبة الكلية و البروتين الكلى والبروتين الذائب والدهن والرماد والحموضة في اللبنه المصنعة من مركز الترشيح الفائق بالمقارنة لتلك المصنعة من

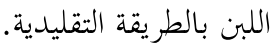
رقم pH كان مرتفعاً في اللبنه المصنعة من مركز الترشيح الفائق على الرغم من إرتفاع الحموضة عن نظيرةًا في اللبنه المخضرة بالطريقة التقليدية وقد أعزى ذلك للسعة التنظيمية العالية buffering capacity 